\title{
Correlation and path coefficient analysis among seed yield and yield related traits of Ethiopian chickpea (Cicer arietinum L.) landraces
}

\author{
Awol MOHAMMED ${ }^{*}$, Asnake FIKRE ${ }^{1}$
}

Received July 13, 2018; accepted November 23, 2018.

Delo je prispelo 13. julija 2018, sprejeto 23. novembra 2018.

\begin{abstract}
The experiment was done on 202 new chickpea (Cicer arietinum L.) landraces with 2 checks to assess the association, direct and indirect effect of different characters on yield. The experiment was planted at Sirinka and Jari, Ethiopia, under rain fed condition in 2016 using alpha lattice design with three replications. Data were collected on yield and yield related traits. Analysis of variance showed highly significant differences among genotypes. The correlation of grain yield with biomass and with harvest index was positive and highly significant both at genotypic and phenotypic levels. In addition, its association with pod filling period, plant height, secondary branches and hundred seed mass was positive but insignificant both at genotypic and phenotypic levels. Path coefficient analysis at genotypic level showed that among the 15 causal (independent) traits; biomass, harvest index, pod length, days to pod setting, pod filing period, canopy width, primary branches, secondary branches, and number of pods per plant had positive and directly influence on grain yield. Although the days to flowering, plant height and hundred seed mass had positive genotypic correlation with grain yield. In general correlation coupled with path coefficient analysis revealed that biomass and harvest index had a direct relationship with seed yield.
\end{abstract}

Key words: chickpea; correlation; path coefficient analysis; seed yield; yield related traits

\section{IZVLEČEK}

\author{
ANALIZA ODVISNOSTI PRIDELKA SEMENA \\ ETIOPSKIH LOKALNIH ZVRSTI ČIČERKE (Cicer \\ arietinum L.) OD S PRIDELKOM POVEZANIH \\ LASTNOSTI
}

Poskus je potekal na 202 novih lokalnih zvrsteh čičerke (Cicer arietinum L.) $\mathrm{z}$ dvema preiskusoma za ovrednotenje neposredne in posredne povezave učinkov različnih lastnosti na pridelek. Poskus je bil izveden leta 2016 v krajih Sirinka in Jari v Etiopiji v razmerah brez namakanja kot nepopolni bločni poskus s tremi ponovitvami. Zbrani so bili podatki o pridelku in z njim povezanimi lastnostmi. Analiza variance je pokazala zelo značilne razlike med genotipi. Povezava med pridelkom z biomaso in žetvenim indeksom je bila pozitivna in zelo značilna na genotipski in fenotipski ravni. Dodatno je bila povezava pridelka pozitivna $\mathrm{z}$ lastnostmi kot so obdobje polnjenja strokov, višina rastlin, število sekundarnih poganjkov in masa stotih semen a nestatistično značina, ne na genotipski niti na fenotipski ravni. Analiza povezav na genotipski ravni je pokazala, da ima 15 znakov (lastnosti) kot so biomasa, žetveni indeks, dolžina stroka, število dni do nastavka strokov, obdobje polnjena strokov, širina nadzemnega dela rastlin, število primarnih in sekundarnih stranskih pogankov in število strokov na rastlino pozitivni in neposredni vpliv na pridelek semena. Tudi lastnosti kot so število dni do cvetenja, višina rastlin in masa stotih semen so imele pozitivne genetske povezave $\mathrm{s}$ pridelkom zrnja. Nasplošno je povezava med znaki povezana s povezavo med posameznimi znaki odkrila, da sta imela biomasa in žetveni indeks neposredno povezavo s pridelkom semena.

Ključne besede: čičerka; korelacija; analiza odvisnosti posameznih znakov; pridelek semena; s pridelkom povezani znaki

\footnotetext{
* Sirinka Agricultural Research Center, P. O.Box 74, Woldia, Ethiopia; *Corresponding author: mawol50@ yahoo.com

1 International Center of Research for Semi Arid Tropics
} 


\section{INTRODUCTION}

Chickpea (Cicer arietinum L.) is the third most important pulse crop in the world, after dry common bean and field pea (Padmavathiv et al., 2013). Southeast Turkey and Syria are considered as the two primary centers of origin of chickpea (Singh et al., 1997). The world chickpea production reached 13.3 million tons in 2013 and 14.2 million tons in 2014 (FAO, 2014). India is the largest chickpea producing country accounting for $72 \%$ of the global chickpea production (Ojiewo, 2016). Ethiopia is considered as one of the secondary centers of diversity for chickpea (van der Maesen, 1987). In Ethiopia, chickpea is the third largest legume crop in area and production (CSA, 2015).

There are two types of chickpea depending on seed color, shape, and size. The Kabuli type has large, round or ram head and cream-colored seeds, and is grown in temperate regions (ICRISAT, 2010). The Desi type chickpea is grown in the semi-arid tropics and is characterized by relatively small angular shaped seeds with light brown, yellowish or black colour.

Chickpea is very important due to its good nutritional value having an average of $4.5 \%$ fat, $8 \%$ crude fiber, $22 \%$ protein, $63 \%$ carbohydrate and $2.7 \%$ ash (Shafiqueet al., 2016). Besides being an important source of human food and animal feed, it is also an important contributor to soil fertility as it provides nitrogen to soil through fixation of atmospheric nitrogen (Gul et al., 2011).

Many international agreements proclaim food security which implies the conservation of plant genetic resources for food and agriculture. The landraces or farmer varieties are important source of the genetic diversity and potential material that could be used to broaden the base for plant breeding. An indigenousness landrace is a variety with a high capacity to tolerate biotic and abiotic stress, resulting in high yield stability and an intermediate yield level under a low input agricultural system (FAO, 1998). Ethiopia has a large number of chickpea landraces cultivated by the farmers through traditional method of selection over a long time. This provides the basic material for developing any variety or hybrid.

Study of yield and yield components provide a basic framework for selecting useful characters in chickpea improvement programs. Seed yield is an important character that is polygenic in nature and significantly influenced by environmental conditions (Singh et al., 2014). Most of plant breeders are interested in maximizing selection efficiency that supports the identification of best genotypes. Estimation of correlation coefficient is useful in planning future breeding and provides a measure of association among traits, which could be useful as a selection guide. The path coefficient analysis enables to determine the direct and indirect contribution of various traits toward yield. Correlation analysis provides information of associations among yield components. Path coefficient analysis permits the separation of the correlation coefficient into component of direct and indirect effects and to measure the relative importance of each (Singh and Chaudhary, 1977; Sharma, 1998). Therefore the objective of this study was to determine the association of different characters with seed yield, direct and indirect influence of characters towards yield and yield contributing traits and assess magnitude to define seed yield.

\section{MATERIALS AND METHODS}

\subsection{Description of Experimental Sites}

The experiment was carried out under rain fed condition at Sirinka and Jari Agricultural stations, Ethiopia. The former one is located at $11^{\circ} 45^{\prime}$ North latitude and $39^{\circ}$ 36' 36 " East longitudes. Its altitude is 1850 meter above sea level located in North Wollo Zone. The annual rainfall of this site is $1006.3 \mathrm{~mm}$ with $13.6{ }^{\circ} \mathrm{C}$ minimum and $26.7^{\circ} \mathrm{C}$ maximum temperature. Jari, is located at $11^{\circ} 21^{\prime}$ North latitude and $39^{\circ} 47^{\prime}$ East longitudes and at an altitude of 1680 meter above sea level in South Wollo Zone. The annual rainfall of this site is $987.3 \mathrm{~mm}$ with $14.2{ }^{0} \mathrm{C}$ minimum and $28.7{ }^{\circ} \mathrm{C}$ maximum temperature. According to Sirinka Agricultural Research Center soil classification (unpublished), the soils of the sites are classified advertises.

\subsection{Experimental Materials and Design}

A total of 202 newly collected Desi type landraces from Amhara, Oromiya and SNNP Regional States were used for this study. The collecting expedition was done on elevations ranging from 1174 to 2660 meter above sea level. The collections were made in $2013(\mathrm{~N}=42)$ and $2016(\mathrm{~N}=160)$. This puts 90 landraces from Amhara region, 91 from Oromiyaand 24 from SNNP. A total of 202 collected landraces with two released varieties as checks, 'Fetenech' (early maturing) and 'Minjar' (high yielder) were tested and characterized for morphological traits. The experiment was planted on 02 September 2016 by using alpha lattice designwith three replications. Each landrace was sown in two rows at 60 $\mathrm{cm}, 30 \mathrm{~cm}$, and $10 \mathrm{~cm}$ spacing between plots, rows, and 
plants, respectively; with $1 \mathrm{~m}$ row length. All agronomic practices were done uniformly for all accessions as required. There was no fertilizer application. For controlling pod borer Karatewas sprayed at the rate of $200 \mathrm{ml} 300$ liter $^{-1} \mathrm{ha}^{-1}$ and picked by hand.

\subsection{Data Collection}

The data of morphological, phenological, and agronomical traits were collected during the growth period of the crop, depending on the descriptors for chickpea (IBPGR, ICRISAT and ICARDA, 1993). The data of plant height, stem colour, number of leaflets per leaf, plant canopy width, number of primary branches, number of secondary branches, pod length, number of pods per plant, number of seeds per pod, days to $50 \%$ flowering, days to $50 \%$ pod setting, pod filling period, days to $75 \%$ maturity, total biomass, hundred seed mass, seed yield, harvest index, seed coat colour, seed shape, diseases and insect damage score (1-9) and seed testa texture were collected.

\subsection{Analysis of variance}

Analysis of variance (ANOVA) was performed for the quantitative data using SAS computer software (SAS, 2004) as per the following linear model for alpha lattice design.

$\mathrm{Y}_{\mathrm{ijk}}=\mu+\mathrm{R}_{\mathrm{i}}+\mathrm{B}_{\mathrm{ij}}+\mathrm{T}_{\mathrm{k}}+\mathrm{e}_{\mathrm{ijk}}$ : where, $\mu=$ the grand mean of trait $\mathrm{Y} ; \mathrm{R}_{\mathrm{i}}=$ the effect of replicate $\mathrm{I} ; \mathrm{B}_{\mathrm{ij}}=$ effect of block $j$ within replicate $I ; T_{k}=$ effect of treatment $k$

\subsection{Phenotypic and genotypic correlation coefficients}

Phenotypic and genotypic correlation were estimated using the formula suggested by Miller et al. (1958)

Phenotypic correlation was computed as:

$\mathrm{r}_{\mathrm{pxy}}=\frac{\sigma^{2} p x y}{\sqrt{\left(\sigma^{2} p x\right)\left(\sigma^{2} p y\right)}}$

Genotypic correlation was computed as:

$\mathrm{r}_{\mathrm{gxy}}=\frac{\sigma^{2} g x y}{\sqrt{\left(\sigma^{2} g x\right)\left(\sigma^{2} g y\right)}}$

Where $r_{p x y}$ is phenotypic correlation coefficient and $r_{\text {gxy }}$ is genotypic correlation coefficient between characters $\mathrm{x}$ and $\mathrm{y} ; \sigma^{2}$ pxy and $\sigma^{2}$ gxy are phenotypic covariance and genotypic covariance between characters $\mathrm{x}$ and y, respectively. $\sigma^{2} \mathrm{px}$ and $\sigma^{2} \mathrm{gx}$ are phenotypic and genotypic variances for character $\mathrm{x}$ and $\sigma^{2}$ py and $\sigma^{2}$ gy are phenotypic and genotypic variances for character $\mathrm{y}$.

The coefficient of correlation at phenotypic level was tested for its significance with table for simple correlation coefficient using $\mathrm{n}-2 \mathrm{df}$ as suggested by Gomez and Gomez (1984) or using ' $t$ ' table, with observed t expressed as

$\mathrm{t}=\frac{r_{p x y} \sqrt{n-2}}{\sqrt{1-r_{p x y}^{2}}}$

The calculated ' $\mathrm{t}$ ' value was compared with the tabulated ' $\mathrm{t}$ ' value at $\mathrm{n}-2$ degree of freedom, $(\mathrm{n}=204)$ at $5 \%$ and $1 \%$ level of significance (where $\mathrm{n}$ is the number of genotypes).

The coefficient of correlation at genotypic level was tested according to Robertson (1959);

$t=\frac{r_{g x y}}{S E r_{g x y}}$ where, $r_{g x y}=$ genotypic correlation coefficient,

$\mathrm{SEr}_{\text {gxy }}=$ standard error of genotypic correlation coefficient

$\operatorname{SEr}_{\mathrm{gxy}}=\sqrt{\left(1-r^{2} g x y\right)^{2} / 2 h_{1}^{2} h_{2}^{2}}$

Where $h^{2}$ and $h^{2}{ }_{2}$ are broad sense heritability for character 1 and 2

The calculated ' $\mathrm{t}$ ' value was compare with the ' $\mathrm{t}$ ' tabulated value at $\mathrm{n}-2(\mathrm{df}=202)$ at the $5 \%$ and $1 \%$ level of significance (where $\mathrm{n}$ is the number of accessions).

\subsection{Path coefficient analysis}

Associations of yield with its components were determined by the application of correlation and path analysis. The use of path analysis requires a cause and effect situation among the variables. Path coefficient analysis was calculated using the formula suggested by Dewey and Lu (1959) to assess direct and indirect effects of different traits on grain yield as:

$$
r_{i j}=p_{i j+} \sum r_{i k} p_{k j}
$$


Where $r_{i j}$ is mutual association between the independent traits (i) and the dependent trait (j) as measured by the correlation coefficient, $p_{\mathrm{ij}}$ is component of direct effect of the independent trait (i) on the dependent variable (j); and $r_{i k} p_{k j}$ is the components of indirect effect of a given independent trait (i) on the dependent traits (j) via all other independent traits $(\mathrm{k})$. The residual effect (U) which is the unexplained variation of the trait that is not accounted for by path coefficient and is calculated using the formula of Dewey and LU (1959) as:

$\mathrm{U}=\sqrt{1-R^{2}}$, where $\mathrm{R}^{2}=\sum r_{i k} p_{k j}$

\section{RESULTS AND DISCUSSION}

\subsection{Analysis of variance}

Analysis of variance revealed highly significant differences $(\mathrm{P}<0.001)$ among genotypes for most of the studied traits indicating genetic variability in the characters studied (Table 1).The magnitude of mean squares due to genotypes was high for grain yield, biomass yield, harvest index and number of pods per plant; while low genotype mean square values exhibited for number of seed per pod, primary branches per plant, pod length, and number of leaflets per leaf (Table 1).Similarly, previous studies on chickpea landraces also reported by (Tesfamickael et al., 2014; Uday et al., 2012).

Table 1: Mean squares, significance and CV \% of morpho - agronomic characters of chickpea germplasm

\begin{tabular}{|c|c|c|c|}
\hline \multirow[t]{2}{*}{ Traits } & \multicolumn{3}{|l|}{ Mean square (CV \%) } \\
\hline & Sirinka & Jari & Combined \\
\hline$\overline{\mathrm{DF}}$ & $24.25 * *(6.56)$ & $23.73 * *(5.04)$ & $4.24^{\mathrm{ns}}(8.2)$ \\
\hline DP & $31.23 * *(6.46)$ & $15.06 * *(4.89)$ & $9.73^{\mathrm{ns}}(4.98)$ \\
\hline PFP & $18.70 * *(6.07)$ & $24.54 * *(5.02)$ & $5.99^{\mathrm{ns}}(6.23)$ \\
\hline $\mathrm{DM}$ & $42.32 * *(4.28)$ & $22.08 * *(5.68)$ & $5.39^{\mathrm{ns}}(4.52)$ \\
\hline $\mathrm{CW}$ & $38.83 * *(8.15)$ & $122.25 * *(11.5)$ & $14.03 *(22.31)$ \\
\hline NLtL & $0.87 * *(5.97)$ & $3.04 *(15.78)$ & $0.79 *(16.23)$ \\
\hline $\mathrm{PH}$ & $31.12 * *(9.85)$ & $96.27 * *(17.60)$ & $8.61 * *(20.13)$ \\
\hline PB & $0.72 * *(19.65)$ & $0.05^{\mathrm{ns}}(21.5)$ & $0.11^{\mathrm{ns}}(28.9)$ \\
\hline SB & $11.11 * *(17.16)$ & $0.62^{\mathrm{ns}}(20.42)$ & $1.88 *(25.61)$ \\
\hline NPP & $520.46 * *(21.02)$ & $267.32 *(28.6)$ & $50.90 * *(30.2)$ \\
\hline NSP & $0.08^{\mathrm{ns}}(12.06)$ & $0.02^{\mathrm{ns}}(15.23)$ & $0.029^{\mathrm{ns}}(11.6)$ \\
\hline PL & $0.24 * *(26.5)$ & $0.65 *(29.42)$ & $0.25 *(31.2)$ \\
\hline HSW & $8.34 * *(13.23)$ & $6.27 * *(12.52)$ & $0.43^{\text {ns }}(8.96)$ \\
\hline GYKH & $441140.22 * *(28.66)$ & $393086.47 * *(24.56)$ & $23558.56^{\mathrm{ns}}(30.2)$ \\
\hline BMKH & $1936174.5 * *(25.97)$ & $1734469.2 *(29.62)$ & $123242.6^{\mathrm{ns}}(32.21)$ \\
\hline $\mathrm{HI}$ & $240.00 * *(21.48)$ & $189.23 *(18.96)$ & $1.42^{\text {ns }}(28.9)$ \\
\hline
\end{tabular}

DF = Days to flowering, DP = Days to pod setting, PFP = Pod filling period, DM = Days to maturity, CW = Canopy width, NLtL $=$ Number of leaflets per leaf, $\mathrm{PH}=$ Plant height, $\mathrm{PB}=$ Primary branches, $\mathrm{SB}=$ Secondary branches, NPP $=$ Number of pods per plant, NSP $=$ Number of seeds per pod, PL $=$ Pod length, HSW $=$ Hundred seed mass, GYKH $=$ Grain yield kilo gram per hectare, $\mathrm{BM}=$ Biomass kilo gram per hectare, $\mathrm{HI}=$ Harvest index, ${ }^{\mathrm{ns}}=$ non significant and $* * *$ significant at $5 \%$ and $1 \%$ probability level, respectively.

This low magnitude of mean squares indicated the traits were relatively sensitive to environmental effects. These results are also confirmed similarly by reports of Zerihun (2011), Feven (2002) and Melese (2005).

\subsection{Correlation studies}

Studies on correlations among agronomic traits and seed yield can supply reliable information on the nature and level of their inter relationships. Identification and exploitation of traits positively attributing to seed yield is essential as it enhances breeding efficiency of chickpea. In this study, genotypic and phenotypic correlation coefficients for all possible combinations among 16 traits are presented in Table 2.

\subsubsection{Association of grain yield with other traits}

The linear correlation coefficient analysis determines the magnitude and degree of relationship between two 
traits. Association between traits could be due to genotypic correlation, which is attributed to linkage between genes or pleiotropic gene effect (Shafique et al., 2016), or due to environmental effect, or both (Falconer and Mackey 1996). The correlation of grain yield with biomass $\left(r_{\mathrm{g}}=0.71\right.$ and $\left.\mathrm{r}_{\mathrm{ph}}=0.72\right)$ and with harvest index $\left(r_{g}=0.52\right.$ and $\left.r_{p h}=0.54\right)$ was positive and highly significant both at genotypic and phenotypic levels. The correlation of grain yield with pod filling period, plant height, secondary branches and hundred seed mass was positive but non-significant both at genotypic and phenotypic levels. Muhammad et al. (2005) reported similar results. On the other hand, the correlation of grain yield with days to maturity, primary branches, and number of seeds per pod was negative but no significant at both levels.

The genotypic correlations of grain yield with days to flowering, days to pod setting, canopy width and number of pods per plant were positive but not significant. On the other hand, grain yield was negatively and non- significantly correlated with number of leaflets per leaf. However, genotypic correlation between grain yield and biomass yield was positive and highly significant, which is in agreement with the reports of Zerihun (2011), Melese (2005), and Tesfamickael et al. (2014).That means breeding for better biomass cultivars could be an indirect selection on chickpea improvement or landrace promotion.

\subsubsection{Associations among other traits}

Days to flowering was positively and significantly correlated with days to maturity, days to pod setting, number of leaflets per leaf, secondary branches, number of pods per plant, and hundred seed mass, but negatively correlated with primary branches at phenotypic and genotypic level (Table 2).Moreover, the genotypic correlation coefficients of days to flowering with these traits were greater than the corresponding phenotypic correlation coefficients, indicating genetic causes for the observed association. As a result, late flowering varieties are expected to take long duration to develop pods and mature late. According to Thakur and Sirohi (2009), genotypic correlation coefficients higher than that of phenotypic correlation coefficients indicate strong inherent association between the traits and the possibility of effective phenotypic selection.

Days to maturity showed significant and positive correlations with days to flowering, days to pod setting, number of leaflets per leaf, canopy width, secondary branches, number of pods per plant, and hundred seed mass at both phenotypic and genotypic levels. This is in agreement with Zerihun (2011). However, the correlation of days to maturity with primary branches and number of seeds per pod was negative at both phenotypic and genotypic levels (Table 2).
Plant height correlated positively and strongly with days to pod setting, number of leaflets per leaf, canopy width, and pod filing period; but negatively associated with number of seeds per pod both at genotypic and phenotypic levels. Primary branches had strong negative correlation with days to pod setting, pod filing period, days to maturity, and secondary branches at genotypic level; and with harvest index at phenotypic level. On the other hand,it had positive and significant correlation with number of pods per plant and number of seeds per pod at phenotypic level.

Secondary branches had high positive correlation with days to flowering, days to pod setting, pod filing period, canopy width, plant height, number of pods per plant, and hundred seed mass at both phenotypic and genotypic levels. However, it showed negative correlation with primary branches at both levels.

Hundred seed mass showed high positive correlation with days to flowering, days to pod setting, days to maturity, plant height, and secondary branches both at genotypic and phenotypic level; but negatively associated with the number of seeds per pod at both levels. Biomass yield had high positive correlation with grain yield at genotypic and phenotypic levels, but negatively correlated with harvest index at both levels (Table 2).Generally, among the 16 traits in this study, biomass and harvest index correlated positively and significantly with grain yield at both genotypic and phenotypic levels.

In general, all positive correlation between grain yield with traits of pod filling period, plant height, secondary branches, hundred seed mass and biomass both at genotypic and phenotypic levels are best traits which are important to direct selection process. 
Awol MOHAMMED, Asnake FIKRE

Table 2: Genotypic (above diagonal) and phenotypic (below diagonal) correlation coefficients among 16 traits of 204 chickpea genotypes

\begin{tabular}{|c|c|c|c|c|c|c|c|c|c|c|c|c|c|c|c|c|}
\hline Trait & DF & $\mathrm{DP}$ & PFP & $\mathrm{DM}$ & $\mathrm{CW}$ & NLtL & $\mathrm{PH}$ & PB & SB & NPP & NSP & HSW & GY & BY & $\mathrm{HI}$ & $\mathrm{PL}$ \\
\hline $\mathrm{DF}$ & & $0.94 * *$ & 0.03 & $0.48 * *$ & $0.24 * *$ & $0.17 *$ & 0.44 & $-0.23 * *$ & $0.32 * *$ & $0.17 *$ & -0.18 & $0.25 * *$ & 0.04 & -0.07 & 0.1 & -0.10 \\
\hline DP & $0.89 * *$ & & 0.09 & $0.44 * *$ & $0.25 * *$ & $0.17 *$ & $0.43 * *$ & -0.25 & $0.32 * *$ & $0.16^{*}$ & $-0.16^{*}$ & $0.27 * *$ & 0.02 & -0.05 & 0.09 & -0.09 \\
\hline PFP & $-0.1 *$ & 0 & & $0.35 * *$ & 0.06 & $0.2^{*}$ & $0.32 * *$ & $-0.2 *$ & $0.19 *$ & $0.16^{*}$ & $-0.17 *$ & $0.2 *$ & 0.06 & 0.01 & 0.06 & 0.1 \\
\hline CW & 0.16 & $0.16 * *$ & $0.12 *$ & $0.18 * *$ & & 0.04 & $0.55 * *$ & -0.05 & $0.42 * *$ & $0.29 * *$ & 0.01 & -0.02 & 0.05 & 0.05 & 0.01 & -0.01 \\
\hline NLtL & $0.11 *$ & $0.11 *$ & $0.09 *$ & $0.16 * *$ & 0 & & $0.18 *$ & -0.11 & 0.09 & -0.02 & 0.04 & 0.05 & -0.06 & -0.07 & 0.01 & -0.03 \\
\hline $\mathrm{PH}$ & $0.34 * *$ & $0.33 * *$ & $0.29 * *$ & $0.37 * *$ & $0.54 * *$ & $0.10^{*}$ & & -0.11 & $0.51 * *$ & $0.5^{* *}$ & $-0.23 *$ & $0.17 *$ & 0.1 & 0.04 & 0.1 & 0.03 \\
\hline PB & $-0.18 * *$ & $-0.2 * *$ & $-0.17 * *$ & $-0.15^{* *}$ & 0.01 & -0.06 & -0.06 & & $-0.14 *$ & 0.07 & 0.06 & 0.06 & -0.05 & 0.03 & -0.12 & -0.03 \\
\hline SB & $0.20 * *$ & $0.22 * *$ & $0.13^{*}$ & $0.19 * *$ & $0.39 * *$ & 0.05 & $0.42 * *$ & -0.06 & & $0.57 * *$ & 0.02 & $0.14 *$ & 0.05 & -0.02 & 0.06 & -0.08 \\
\hline NPP & $0.12 *$ & $0.12 *$ & $0.16^{* *}$ & $0.15 * *$ & $0.32 * *$ & -0.03 & $0.46 * *$ & $0.08 *$ & $0.55^{* *}$ & & 0.04 & 0.05 & 0.02 & 0.01 & -0.03 & 0.01 \\
\hline NSP & -0.13 & $-0.13^{*}$ & $-0.11 *$ & $-0.1^{*}$ & 0.06 & 0.07 & $-0.12 *$ & $0.08 *$ & 0.06 & 0.08 & & $-0.2 *$ & -0.08 & -0.04 & -0.06 & -0.07 \\
\hline HSW & $0.18 * *$ & $0.18 * *$ & 0.13 & $0.11 *$ & -0.01 & 0.01 & $0.12 *$ & 0.04 & $0.09 *$ & 0.05 & $-0.14 *$ & & 0.07 & 0.09 & -0.02 & -0.04 \\
\hline GY & -0.04 & -0.02 & 0.06 & -0.02 & -0.02 & 0.04 & 0.05 & -0.05 & 0.02 & -0.01 & -0.06 & 0.04 & & $0.72 * *$ & $0.54 * *$ & -0.02 \\
\hline BY & $-0.1 *$ & -0.07 & 0.06 & -0.01 & 0.01 & -0.03 & 0.02 & 0.02 & 0.03 & -0.03 & -0.03 & 0.05 & $0.71 * *$ & & $-0.18 *$ & -0.04 \\
\hline HI & 0.06 & 0.06 & 0.01 & -0.01 & -0.05 & 0.07 & 0.04 & $-0.10^{*}$ & $0.03 *$ & -0.01 & -0.05 & -0.04 & $0.52 * *$ & $-0.22 * *$ & & 0.02 \\
\hline PL & -0.06 & -0.07 & 0.04 & $-0.03 *$ & 0.01 & -0.04 & 0.01 & -0.01 & -0.06 & -0.04 & 0.03 & -0.03 & 0.04 & -0.03 & 0.07 & \\
\hline
\end{tabular}

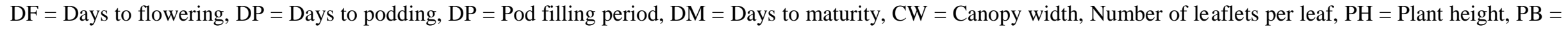

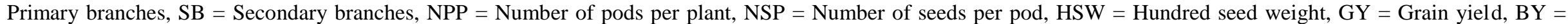
Biomass, $\mathrm{HI}=$ Harvest index, $\mathrm{PL}=$ Pod length, and $*$, ** significant at $5 \%$ and $1 \%$ probability level, respectively 


\subsection{Path coefficient analysis}

Grain yield is a resultant trait of many component traits, known as yield components. Associations between yield and yield components as determined by correlation coefficients do not indicate the relative importance of the direct and indirect effect of associated trait on grain yield. Hence, path coefficient analysis would give the opportunity to see grain yield as the dependent variable and other traits as casual factors (independent variables). The results of genotypic path coefficient analysis are given in Table 3.

Path coefficient analysis at genotypic level showed that among the fifteen traits; biomass (0.84), harvest index (0.69), pod length (9.73), days to pod setting (0.024), pod filing period $(0.020)$, canopy width $(0.003)$, primary branches (0.007), secondary branches (0.003), and number of pods per plant $(0.019)$ had positive directly influence on grain yield.

Other traits such as days to flowering $(-0.016)$, days to maturity (-0.015), number of leaflets per leaf $(-0.004)$, plant height (-0.019), number of seeds per pod $(-0.002)$, and hundred seed mass (-0.002) had negative direct effects on grain yield. These study findings are also in line with the reports of Yucel et al. (2006), Yucel and Anlarsal (2010), Ali et al. (2011) and Jadhav et al. (2014) in chickpea. Padmavathi et al., (2013) also reported high positive direct effects of biological yield, number of pods per plant, and harvest index on grain yield signifying the importance of these traits in improvement of grain yield.

Pod length exerted the highest direct effect (9.73), and also positive indirect effects on grain yield via pod filing period, plant height, number of pods per plant, and harvest index. However, the positive direct effect of pod length on grain yield was counter balanced by relatively high negative indirect effects via days to flowering, days to pod setting, days to maturity, canopy width, number of leaflets per leaf, primary branches, secondary branches, number of seeds per pod, hundred seed mass and biomass; which resulted in negative correlation with grain yield $\left(r_{\mathrm{g}}=-1.44\right)$ (Table 3). Biomass yield exerted the second highest positive direct effect (0.84) on grain yield. It also exhibited positive indirect effects on grain yield through pod filing period, canopy width, plant height, primary branches, number of pods per plant and hundred seed mass. However, it had high negative indirect effects on grain yield through days to flowering, days to pod setting, days to maturity, number of leaflets per leaf, secondary branches, and number of seeds per pod, harvest index, and pod length.

Although the days to flowering, plant height and hundred seed mass had positive genotypic correlation with grain yield, their direct effects on grain yield were negative. This imply that the observed positive correlations of these traits with grain yield were due to their indirect positive effects on grain yield through primary branches, number of seeds per pod, biomass, pod length, canopy width and harvest index. This indicates the importance of these traits in the breeding program to identify high yielding genotypes through indirect selection for these traits. According to Singh and Chaudhary (1977), whenever a character has positive association and high positive indirect effects but negative direct effect on economic trait like grain yield, emphasis should be given to the indirect effects.

The estimated residual effect of path analysis was low (0.156), which indicated that about $85 \%$ of the variability in grain yield was contributed by the traits studied. This residual effect towards grain yield in the present study might be due to other characters or environmental factors and, or sampling errors (Sengupta and Kataria, 1971).

According to the path coefficient analysis at phenotypic level biomass (0.86), harvest index (0.71), pod length (0.01), days to pod setting (0.021), primary branches (0.004) hundred seed mass (0.003) and number of pods per plant (0.011) had positive directly influence on grain yield and signifying the importance of these traits in improvement of grain yield (Table 4).

Other traits such as days to flowering (-0.02), days to maturity $(-0.004)$, number of leaflets per leaf $(-0.02)$, plant height $(-0.04)$, canopy width $(-0.01)$,), secondary branches (-0.04), and pod filing period (-0.01) had negative direct effects on grain yield (Table 4 ).

The estimated residual effect of path analysis was low (0.168), which indicated that about $84 \%$ of the variability in grain yield was contributed by the traits studied. This residual effect towards grain yield in the present study might be due to other characters or environmental factors and, or sampling errors (Sengupta and Kataria, 1971). 
Awol MOHAMMED, Asnake FIKRE

Table 3: Genotypic direct (bold, underlined and diagonal) and indirect effects of 15 traits on grain yield for 204 chickpea genotypes

\begin{tabular}{|c|c|c|c|c|c|c|c|c|c|c|c|c|c|c|c|}
\hline Traits & DF & DP & PFP & $\mathrm{DM}$ & $\mathrm{CW}$ & NLtL & $\mathrm{PH}$ & PB & SB & NPP & NSP & HSM & $\mathrm{BM}$ & HI & PL \\
\hline $\mathrm{DF}$ & $\underline{-0.016}$ & 0.023 & 0.001 & -0.07 & 0.001 & -0.02 & -0.09 & -0.02 & 0.001 & 0.003 & 0.001 & -0.01 & -0.06 & 0.069 & -9.82 \\
\hline DP & -0.015 & $\underline{0.024}$ & 0.002 & -0.06 & 0.001 & -0.01 & -0.08 & -0.02 & 0.001 & 0.003 & 0.001 & -0.01 & -0.04 & 0.061 & -8.33 \\
\hline PFP & -0.001 & $\overline{0.002}$ & $\underline{\mathbf{0 . 0 2 0}}$ & -0.05 & 0.002 & -0.01 & -0.06 & -0.05 & 0.001 & 0.003 & 0.001 & -0.01 & 0.010 & 0.04 & 9.60 \\
\hline DM & -0.007 & 0.010 & $\overline{0.006}$ & $\underline{-0.02}$ & 0.001 & -0.01 & -0.08 & -0.01 & 0.001 & 0.003 & 0.001 & -0.01 & -0.02 & 0.009 & -6.25 \\
\hline $\mathrm{CW}$ & -0.004 & 0.006 & 0.001 & $\overline{-0.03}$ & $\underline{0.003}$ & -0.01 & -0.01 & -0.01 & 0.001 & 0.005 & -1.3 & 3.49 & 0.044 & 0.004 & -6.72 \\
\hline NLtL & -0.003 & 0.004 & 0.003 & -0.03 & 0.001 & $\underline{-0.04}$ & -0.04 & -0.01 & 0.001 & -0.01 & -6.2 & -0.01 & -0.06 & 0.007 & -3.04 \\
\hline $\mathrm{PH}$ & -0.007 & 0.010 & 0.006 & -0.06 & 0.002 & $\overline{-0.01}$ & $\underline{-0.02}$ & -0.01 & 0.002 & 0.009 & 0.001 & -0.01 & 0.035 & 0.067 & 3.31 \\
\hline PB & 0.004 & -0.06 & -0.04 & 0.03 & -0.01 & 0.001 & $\overline{0.002}$ & $\underline{0.01}$ & -0.01 & 0.001 & -0.01 & -0.01 & 0.024 & -0.08 & -2.77 \\
\hline SB & -0.005 & 0.007 & 0.003 & -0.03 & 0.001 & -0.01 & -0.01 & -0.01 & $\underline{\mathbf{0 . 0 0 3}}$ & 0.011 & -2.7 & -0.01 & -0.02 & 0.041 & -7.56 \\
\hline NPP & -0.003 & 0.003 & 0.003 & -0.02 & 0.001 & 6.48 & -0.09 & 0.001 & $\overline{0.001}$ & $\underline{0.019}$ & -7.4 & -0.01 & 0.007 & -0.02 & 1.30 \\
\hline NSP & 0.003 & -0.04 & -0.03 & 0.02 & 2.42 & -0.01 & 0.004 & 0.001 & 5.22 & 0.001 & $\underline{-0.02}$ & 0.001 & -0.03 & -0.04 & -6.99 \\
\hline HSW & -0.004 & 0.007 & 0.004 & -0.02 & -4.8 & -0.02 & -0.03 & 0.005 & 0.001 & 0.001 & 0.004 & $\underline{-0.02}$ & 0.08 & -0.01 & -3.90 \\
\hline BY & 0.001 & -0.01 & 0.001 & 4.82 & 0.002 & 0.001 & -0.01 & 0.001 & -6.1 & 0.001 & 6.9 & -0.01 & $\underline{0.84}$ & -0.12 & -3.71 \\
\hline HI & -0.002 & 0.002 & 0.001 & -0.01 & 2.02 & -3.7 & -0.01 & -0.01 & 0.001 & -6.2 & 0.001 & 4.37 & -0.15 & $\underline{0.69}$ & 2.18 \\
\hline PL & 0.001 & -0.01 & 0.002 & 0.01 & -2.2 & 1.11 & -0.01 & -0.01 & -0.01 & 0.001 & 0.001 & 9.37 & -0.03 & 0.02 & $\underline{9.73}$ \\
\hline
\end{tabular}

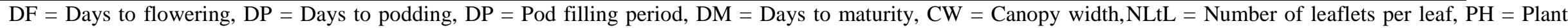

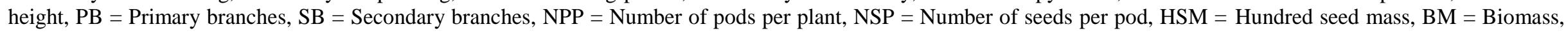
$\mathrm{HI}=$ Harvest index, $\mathrm{PL}=$ Pod length $;$ Residual $=\mathbf{0 . 1 5 6}$ 
In general the information obtained from path analysis revealed that number of pods per plant, biomass, harvest index, secondary branches per plant, canopy width, days to podding and pod filing period had positive direct effect on grain yield at both genotypic and phenotypic levels. Thus, these traits may be used as effective selection parameters for obtaining high yield in breeding programme for yield enhancement in chickpea.

\section{CONCLUSSION}

The correlation of grain yield with biomass and harvest index was positive and highly significant both at genotypic and phenotypic levels. In addition, its association with pod filling period, plant height, secondary branches and hundred seed mass was positive both at genotypic and phenotypic levels.In general, all positive correlation between grain yield with traits of pod filling period, plant height, secondary branches, hundred seed mass and biomass both at genotypic and phenotypic levels are best traits which are important to direct selection process. Path coefficient analysis at genotypic level showed that among the fifteen causal (independent) traits; biomass, harvest index, pod length, days to pod setting, pod filing period, canopy width, primary branches, secondary branches and number of pods per plant had positive direct effects on grain yield per plot.In generalthe information obtained from path analysis revealed that number of pods per plant, biomass, harvest index, secondary branches per plant, canopy width, days to podding and pod filing period had positive direct effect on grain yield at both genotypic and phenotypic levels. Thus, these traits may be used as effective selection parameters for obtaining high yield in breeding programme for yield enhancement in chickpea.

\section{ACKNOWLEDGEMENTS}

First of all, the authors deepest gratitude and acknowledge goes to Amhaera Agricultural Research Institute and/or Sirinka Agricultural Research Center for providing research budget and facilitate the process. We would like also to express sincere thanks to Sirinka Agricultural Research Center pulse case team members for contributing their great effort this successful accomplishment of the experiment.

\section{REFERENCES}

Ali Q, Tahir MHN, Sadaqat HA, Arshad S, Farooq J, Ahsan M, Waseem M, Iqbal A (2011). Genetic variability and correlation analysis for quantitative traits in chickpea genotypes (Cicer arietinum L.). Jornal of Bacteria Research, 3, 6-9.

Central Statistical Authority (2014/2015). Agricultural Sample Survey, Volume I:Report on Area and Production for major crops (Meher Season) Statistical Bulletin No. 578 Addis Ababa, Ethiopia

Dewey, J.R and K.H. Lu (1959). A correlation and path coefficient analysis of yield components of crested wheat seed production.AgronomyJournal,51, 515518.doi:10.2134/agronj1959.000219620051000900 $02 \mathrm{x}$

Falconer, D.S. and T.F.C. Mackay (1996). Introduction to Quantitative Genetics, $4^{\text {th }}$, ed. Longma Group Limited, Malaysia. 438 p

FAO.(1998). The state of ex situ conservation. Page 90 in the state of world's plant genetic resources for food and agriculture. Rome, Italy: Food and Agriculture Organization of the United Nations.
Feven W. (2002). Morphological and biochemical diversity analysis in chickpea (Cicer arietinum L.) landraces of Ethiopia. M.Sc. Thesis submitted to Addis Ababa University,Addis Ababa

Gomez, A.K. and Gomez A.A. (1984).Statistical procedure for agricultural research. John Wiley and Sons $680 \mathrm{p}$.

Gul R., Khan H., Sattar S, Farhatullah, Munsif F, Shadman, Khan BSA, Khattak SH, Arif M, Ali A. (2011). Comparison among nodulated and non nodulated chickpea genotypes.Sarhad Journal of Agriculture,27(4), 577-581.

IBPGR, ICRISAT and ICARDA. (1993). Descriptor for chickpea (Cicer arietinum L.). International Board for Plant Genetic Resources, Italy; International Crop Research Institute for the Semi-Arid Tropics, Patancheru, India and International Center for Agricultural Research in Dry Areas, Aleppo, Syria.

ICRISAT (International crop research institute for semi arid tropics) (2010). 
Pooran M. Gaur, Shailesh Tripathi, CL Laxmipathi Gowda, GV Ranga Rao, HC Sharma, Suresh Pande and Mamta Sharma, Patancheru 502324 Andhra Pradesh, India 2010. Chickpea Seed Production Manual.

Melese D., (2005). Morphological and Random Amplified Polymorphic DNA (RAPD) marker variation analysis in some drought tolerance and susceptible chickpea (Cicer arietinum L.) genotypes; Thesis submitted to University of Addis Ababa, Ethiopia.

Ojiewo Chris (2016). Presentation of Chickpea Production, Technology Adoption and Market Linkages in Ethiopia on Pan-African Grain Legume and World Cowpea Conference Livingstone Zambia Feb 28 - Mar 4, 2016

Padmavathi P.V, Sreemannarayana S, Murthy, V. Satyanarayana Rao and Lal Ahamed M. (2013). Correlation and Path Coefficient Analysis in Kabuli Chickpea (Cicer arietinum L.) on International Journal of Applied Biology and Pharmaceutical Technology,

Robertson, G.E. (1959). The sampling variance of genetic correlation coefficient. Biometrics, 15, 469-485.

SAS Institute 2004 SAS/STAT guide for personal computers, version 9.0 edition, SAS Institute Inc. Cary, NC.

Sengupta, K. and Kataria A.S. 1971.Path coefficient analysis for some characters in soybean. Indian Jornal of Genetics, 31, 290-295.

Shafique MS, Ahsan M, Mehmood Z, Abdullah M, Shakoor A, Ahmad MI. (2016). Genetic variability and interrelationship of various agronomic traits using correlation and path analysis in Chickpea (Cicer arietinum L.). Acadamic Journal of Agricultural Research, 4(2), 082-085.

Sharma J.R. (1998). Statistical and biometrical techniques in plant breeding. New Age International (P) Limited Publishers. New Delhi. $432 \mathrm{p}$.

Singh, R.K and Chaudhary. (1977). Biometrical methods in quantitative genetic analysis.

Kalyani Publisher, New Delhi, Ludhiana, India.300 p.

Singh, K. B., M. Omar, M. C. Saxena, and C. Johansen (1997). Screening for drought resistance in spring chickpea in the Mediterranean region. Journal of
Agronomy \& Crop Science, 178, 22-235. doi:10.1111/j.1439-037X.1997.tb00495.X

Singh JL, Prasad C, Madakemohekar AH, Bornare SS (2014). Genetic variability and character association in diverse genotypes of barley (Hordeum vulgare L.). The Bioscan (Supplement on Genetics and Plant Breeding), 9(2),759-761.

Tesfamichael Semere Mullu, Stephen Githiri Mwangi, Aggrey Bernard Nyende, N. V. P. R Ganga Rao, Damaris Achieng Odeny, Abhishek Rathore and Anil Kumars (2014). Assessment of genetic variation and heritability of agronomic traits in chickpea (Cicer arietinum L). International Journal of Agronomy and Agricultural Research. (IJAAR) ISSN: 2223-7054 (Print) 2225-3610 (Online) http://www.innspub.net Vol. 5, No. 4, p. 76-88, 2014.

Thakur, S.K. and Sirohi, A. (2009). Correlation and path coffient analysis in chickpea (Cicer arietinum L.) under different seasons. Legume Research, 32, 1-6.

Uday Chand Jha1, Singh D.P. and Roopa Lavanya (2012). Assessment of genetic variability and correlation of important yield related traits in chickpea (Cicer arietinum L.). Department of Genetics and Plant Breeding G.B. Pant University of Agriculture \& Technology, Pantnagar-263 145 India agricultural research communication centre www.arccjournals.com Indian journals.comLegume Research, 35 (4), 341 - 344.

Van der Maesen LJG (1987). Origin, history and taxonomy of chickpea. In: Saxena MC, Singh KB (eds) The Chickpea. Wallingford: C.A.B International, pp. 11-34.

Yucel DO, Anlarsal AE, Yucel C (2006). Genatic Variabilty, Correalation and Path Analysis of Yield and Yield Components in Chickpea (Cicer arietinum L.). Turky Journal of Agriculture, 30, 182-188.

Yucel DO and Anlarsal AE. (2010). Determination of selection criteria with path coefficient analysis in chickpea (Cicer arietinum L.) breeding. Bulgarian Journal of Agricultural Science, 16(1), 42-48.

Zerihun J. B. (2011). Genetic diversity of elite chickpea (Cicer arietinum L.) varieties using morphological and inter simple sequence repeat markers. Thesis Submitted to the College of Natural and Computational Sciences, Department f Biology, School of Graduate Studies Haramaya University, Haramaya 2011. 